\title{
Inhibition of the Association of Proteoglycans with Cultured Vascular Endothelial Cell Layers by Calcium and Sodium Spirulan
}

\author{
Toshiyuki Kaji, ${ }^{, a}{ }_{a}$ Satomi Shimada, ${ }^{a}$ Chika Yamamoto, ${ }^{a}$ Yasuyuki Fujiwara, ${ }^{a}$ Jung-Bum Lee, ${ }^{b}$ \\ and Toshimitsu Hayashi ${ }^{b}$ \\ ${ }^{a}$ Department of Environmental Health, Faculty of Pharmaceutical Sciences, Hokuriku University, Ho-3 Kanagawa-machi, Kanazawa \\ 920-1181, Japan and ${ }^{b}$ Department of Pharmacognosy, Faculty of Pharmaceutical Sciences, Toyama Medical and Pharmaceutical \\ University, 2630 Sugitani, Toyama 930-0194, Japan
}

(Received January 16, 2002; Accepted January 29, 2002)

\begin{abstract}
Vascular endothelial proteoglycans exhibit an antithrombogenic activity by activating antithrombin III and heparin cofactor II on the luminal surface of the vascular wall. Calcium spirulan (Ca-SP) is a novel sulfated polysaccharide isolated from the blue-green alga Spirulina platensis. Since Ca-SP exhibits antithrombin activity by activation of heparin cofactor II, we hypothesized that the polysaccharide may influence the metabolism of anticoagulant proteoglycans synthesized by endothelial cells. When cultured bovine aortic endothelial cells were treated with Ca-SP $(50 \mu \mathrm{g} / \mathrm{ml}$ or less) in the presence of $\left[{ }^{35} \mathrm{~S}\right]$ sulfate for $24 \mathrm{hr}$, the accumulation of labeled proteoglycans in the cell layer was decreased but that in the conditioned medium was significantly increased, indicating that Ca-SP inhibits the association of proteoglycans with vascular endothelial cell layers. Na-SP, which was prepared by replacement of calcium ion with sodium ion, showed an equal effect. When the endothelial cells were labeled with $\left.{ }^{35} \mathrm{~S}\right]$ sulfate and then treated with Ca-SP $(5 \mu \mathrm{g} / \mathrm{ml}$ or more) for $1 \mathrm{hr}$ in the absence of $\left[{ }^{35} \mathrm{~S}\right]$ sulfate, the percentage of $\left[{ }^{35} \mathrm{~S}\right]$ sulfate-labeled proteoglycans released into the medium was markedly increased by Ca-SP. DEAE-Sephacel ion exchange chromatography of ${ }^{[35}$ S $]$ sulfate-labeled proteoglycans released into the medium from Na-SP-treated cells indicated that NaSP stimulates the release of both heparan and chondroitin/dermatan sulfate proteoglycans from the cell layer. Taking these results together it is suggested that $\mathrm{Ca}-\mathrm{SP}$ and Na-SP promote the release of proteoglycans from vascular endothelial cells by inhibiting the association of the macromolecules with the cell layer.
\end{abstract}

\footnotetext{
*To whom correspondence should be addressed: Department of Environmental Health, Faculty of Pharmaceutical Sciences, Hokuriku University, Ho-3 Kanagawa-machi, Kanazawa 9201181, Japan. Tel. \& Fax: +81-76-229-6208; E-mail: t-kaji@ hokuriku-u.ac.jp
}

Key words — calcium spirulan, endothelial cell, proteoglycan, sodium spirulan, extracellular matrix, vascular

\section{INTRODUCTION}

Calcium and sodium spirulans ( $\mathrm{Ca}-\mathrm{SP}$ and $\mathrm{Na}-$ $\mathrm{SP}$, respectively) are novel sulfated polysaccharides isolated from a hot water extract of the blue-green alga Spirulina platensis. ${ }^{1,2)}$ Structural analysis of Ca$\mathrm{SP}$ indicated that the polysaccharide is composed of rhamnose, 3- $O$-methylrhamnose (acofriose), 2,3-di$\mathrm{O}$-methylrhamnose, 3- $\mathrm{O}$-methylxylose, uronic acids and sulfate, and the backbone consists of 1,3-linked rhamnose and 1,2-linked 3-O-methylrhamnose units with some sulfate substitution at the 4-position; the polymer is terminated at the nonreducing end by 2,3di- $O$-methylrhamnose and 3-O-methylxylose residues. ${ }^{3)}$ Recently, it was confirmed that Ca-SP contains two types of disaccharide repeating units, $O$ hexuronosyl-rhamnose (aldobiuronic acid) and $O$ rhamnosyl-acofriose with sulfated groups. ${ }^{4)}$

$\mathrm{Ca}-\mathrm{SP}$ and Na-SP exhibit antithrombin activity by activation of heparin cofactor $\mathrm{II}^{5)}$ which is a physiological inhibitor of thrombin, in a different mechanism from that of heparin. ${ }^{6)}$ In addition to the direct action to heparin cofactor II, Ca-SP and Na-SP stimulate the synthesis of tissue plasminogen activator but not plasminogen activator inhibitor type 1 in human fetal lung fibroblasts, ${ }^{7)}$ suggesting that the polysaccharides may enhance the fibrinolytic activity in the blood. However, it has been unclear whether Ca-SP and $\mathrm{Na}$-SP can modulate the antithrombogenic activity of vascular endothelial cells.

Vascular endothelial cells are a cell type that 
covers the inner surface of the vascular wall and has antithrombogenic properties by synthesizing and secreting anticoagulant substances such as prostacyclin $^{8)}$ (which has a potent preventative activity against platelet aggregation) and tissue plasminogen activator ${ }^{9)}$ (which converts plasminogen to plasmin that degrades fibrin). Proteoglycans are macromolecules which are composed of a core protein and one or more glycosaminoglycan side chains as a common feature. Vascular endothelial cells synthesize and secrete a large heparan sulfate proteoglycan (HSPG) perlecan and a small chondroitin/dermatan sulfate proteoglycan (CS/DS PG) biglycan. ${ }^{10)}$ Perlecan and biglycan exhibit an antithrombin activity by activation of antithrombin III and heparin cofactor II, respectively. ${ }^{11,12)}$

Metabolism of proteoglycans has been implicated in the modulation of endothelial cell functions such as proliferation ${ }^{13)}$ as well as abnormal behavior of vascular smooth muscle cells. ${ }^{14)}$ Recently, we found that Ca-SP inhibits the repair of wounded monolayers of vascular endothelial cells through inhibition of the proliferation, ${ }^{15)}$ indicating that $\mathrm{Ca}$ SP may influence the metabolism of proteoglycans in the cells. The present study was undertaken to clarify the alteration of proteoglycan metabolism by $\mathrm{Ca}-\mathrm{SP}$ and $\mathrm{Na}-\mathrm{SP}$ as anticoagulant agents in vascular endothelial cells using a cell culture system of the cells.

\section{MATERIALS AND METHODS}

Materials — Vascular endothelial cells from bovine aorta were purchased from Dainippon Pharmaceutical (Osaka, Japan). Dulbecco's modified Eagle's medium (DMEM) and bovine fetal serum were from Nissui Pharmaceutical (Tokyo, Japan) and EquitechBio (Kerrville, TX, U.S.A.), respectively. ASF 301 medium was from Ajinomoto (Tokyo, Japan). Tissue culture plates and dishes were obtained from Iwaki Glass (Chiba, Japan). DEAE-Sephacel, benzamidine, Tris base and phenylmethanesulfonyl fluoride were from Sigma. ${ }^{35} \mathrm{~S} \mathrm{NaSO}_{4}$ (carrier free) was purchased from ICN Biomedicals (Irvine, CA, U.S.A.). Cetylpyridinium chloride (CPC) and other reagents were from Nacalai Tesque (Kyoto, Japan). Incorporation of $\left.{ }^{35} \mathrm{~S}\right]$ Sulfate into Proteoglycans Vascular endothelial cells were cultured in DMEM supplemented with $10 \%$ fetal bovine serum in 24-well culture plates or $100-\mathrm{mm}$ dishes at $37^{\circ} \mathrm{C}$ in $5 \% \mathrm{CO}_{2}$ in air until confluent. The medium was discarded and the cell layer was washed twice with serum-free ASF 301 medium, then incubated at $37^{\circ} \mathrm{C}$ for $24 \mathrm{hr}$ in fresh serum-free ASF 301 medium with Ca-SP or Na-SP $(10,20,30,40$ or $50 \mu \mathrm{g} / \mathrm{ml})$ in the presence of $\left[{ }^{35} \mathrm{~S}\right]$ sulfate $(1 \mathrm{MBq} / \mathrm{ml})$. After incubation, the conditioned medium was harvested and solid urea was added to a concentration of $8 \mathrm{M}$. The cell layer was washed twice with ice-cold $\mathrm{Ca}$, $\mathrm{Mg}$-free phosphate-buffered saline and extracted with $8 \mathrm{M}$ urea solution containing $0.1 \mathrm{M} 6$ aminohexanoic acid, $5 \mathrm{mM}$ benzamidine, $10 \mathrm{mM}$ $N$-ethylmaleimide, $2 \mathrm{mM}$ EDTA, $0.1 \mathrm{M}$ phenylmethanesulfonyl fluoride, $0.1 \mathrm{M} \mathrm{NaCl}, 50 \mathrm{mM}$ Tris base and $2 \%$ Triton $\mathrm{X}-100(\mathrm{pH} 7.5)$ at $4^{\circ} \mathrm{C}$ for $15 \mathrm{~min}$ and the cell layer extract was harvested by scraping with a rubber policeman. The incorporation of $\left[{ }^{35} \mathrm{~S}\right]$ sulfate into proteoglycans was determined by the CPC precipitation method. ${ }^{16)}$ Briefly, portions of the medium and cell layer extracts were spotted on filter papers and washed five times for $1 \mathrm{hr}$ in $1 \%$ $\mathrm{CPC}$ with $0.05 \mathrm{M} \mathrm{NaCl}$. The radioactivity of precipitated proteoglycans on the dried filter paper was measured by liquid scintillation counting.

Release of $\left.{ }^{35} \mathrm{~S}\right]$ Sulfate-labeled Proteoglycans from Endothelial Cell Layers — Confluent cultures of vascular endothelial cells in 24-well culture plates were labeled with $\left[{ }^{35} \mathrm{~S}\right]$ sulfate $(1 \mathrm{MBq} / \mathrm{ml})$ for $24 \mathrm{hr}$. After labeling, the medium was discarded and the cell layer was washed twice with serum-free ASF 301 medium, then incubated at $37^{\circ} \mathrm{C}$ for $1 \mathrm{hr}$ with Ca-SP $(2.5,5,10,25 \mu \mathrm{g} / \mathrm{ml})$ in the absence of $\left.{ }^{35} \mathrm{~S}\right]$ sulfate. The radioactivity of proteoglycans released into the medium and remaining in the cell layer was determined by the CPC precipitation method as described above. The percentage of $\left[{ }^{35} \mathrm{~S}\right]$ sulfate-labeled proteoglycan release was calculated by dividing the radioactivity in the medium by that found in both the medium and the cell layer.

DEAE-Sephacel Chromatography — The released $\left[{ }^{35} \mathrm{~S}\right]$ sulfate-labeled proteoglycans from the cell layer treated with Na-SP $(10 \mu \mathrm{g} / \mathrm{ml})$ for $3 \mathrm{hr}$ were separated into HSPGs and CS/DS PGs on the basis of differences in charge density by DEAE-Sephacel ion exchange chromatography. The proteoglycans extracted from the conditioned medium were applied to DEAE-Sephacel ( $5 \mathrm{ml}$ of resin) in $8 \mathrm{M}$ urea buffer (pH 7.5) containing $2 \mathrm{mM}$ EDTA, $0.25 \mathrm{M} \mathrm{NaCl}$, $0.5 \%$ Triton $\mathrm{X}-100$, and $50 \mathrm{mM}$ Tris base. Unbound radioactivity was removed from the column by washing with $30 \mathrm{ml}$ of the buffer. Bound radioactivity was eluted from the column with a linear gradient of $0.25-0.7 \mathrm{M} \mathrm{NaCl}$ in the urea buffer (total volume 

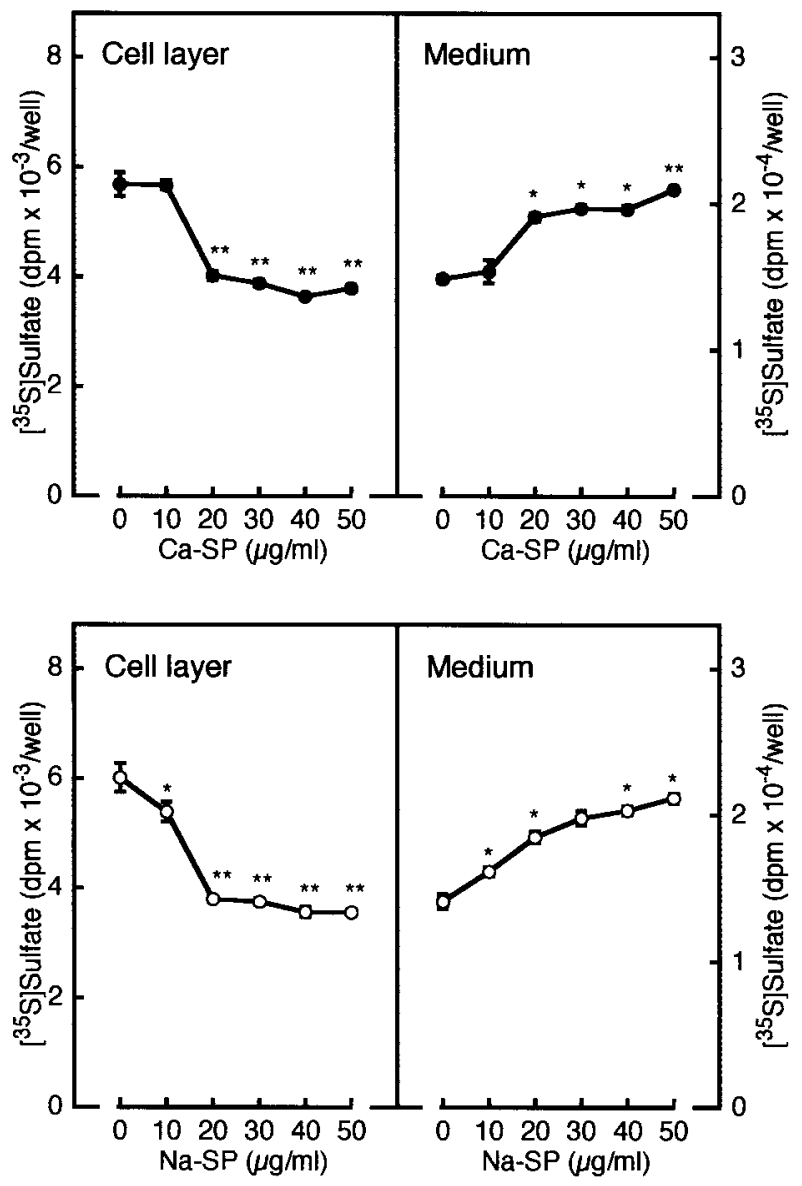

Fig. 1. Incorporation of $\left[{ }^{35} \mathrm{~S}\right]$ Sulfate into Proteoglycans Accumulated in the Cell Layer and the Conditioned Medium of Vascular Endothelial Cells Treated with CaSP (Upper Panels, Closed Circles) or Na-SP (Lower Panels, Open Circles)

Confluent cultures of bovine aortic endothelial cells were incubated at $37^{\circ} \mathrm{C}$ for $24 \mathrm{hr}$ with Ca-SP or Na-SP $(10,20,30,40$ or $50 \mu \mathrm{g} / \mathrm{ml}$ each) in the presence of $\left[{ }^{35} \mathrm{~S}\right]$ sulfate. Values are means \pm S.E. of four samples. Significantly different from the corresponding control, ${ }^{*} p<0.05$; $* * p<0.01$.

of $50 \mathrm{ml}$ ); in this chromatography, HSPGs and CS/ DS PGs were eluted at $\sim 0.45 \mathrm{M}$ and $0.55 \mathrm{M} \mathrm{NaCl}$, respectively. ${ }^{10)}$

Statistical Analysis — Data on the accumulation and release of $\left.{ }^{35} \mathrm{~S}\right]$ sulfate-labeled proteoglycans were analyzed for statistical significance by ANOVA. $p$ Values of less than 0.05 were considered to indicate statistically significant differences.

\section{RESULTS}

Figure 1 shows the accumulation of $\left[{ }^{35} \mathrm{~S}\right]$ sulfatelabeled proteoglycans in the cell layer and the conditioned medium of vascular endothelial cells after

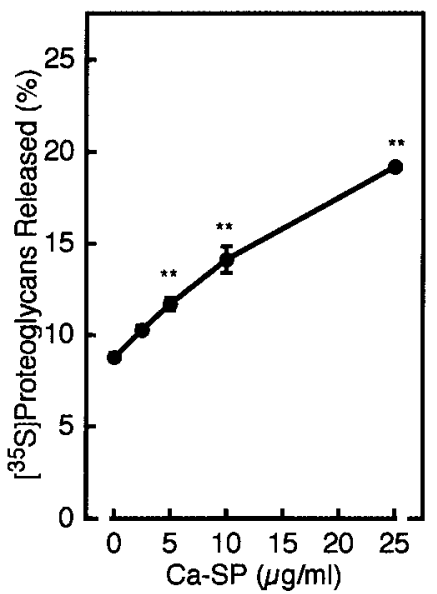

Fig. 2. Effect of Ca-SP on the Release of $\left[{ }^{35} \mathrm{~S}\right]$ Sulfate-labeled Proteoglycans from Vascular Endothelial Cell Layers

Confluent cultures of bovine aortic endothelial cells were labeled with $\left.{ }^{35} \mathrm{~S}\right]$ sulfate and then incubated at $37^{\circ} \mathrm{C}$ for $1 \mathrm{hr}$ with Ca-SP $(2.5,5$, 10 or $25 \mu \mathrm{g} / \mathrm{ml})$ in the absence of $\left[{ }^{35} \mathrm{~S}\right]$ sulfate. Values are means \pm S.E. of four samples. ${ }^{* *}$ Significantly different from the control, $p<0.01$.

treatment with Ca-SP. As shown, the accumulation in the cell layer was significantly decreased whereas that in the conditioned medium was increased by $\mathrm{Ca}-\mathrm{SP}$ in a dose-dependent manner. A similar result was obtained when the cells were treated with $\mathrm{Na}-$ SP. These results indicated that $\mathrm{Ca}-\mathrm{SP}$ and $\mathrm{Na}-\mathrm{SP}$ inhibit the association of proteoglycans newly synthesized by vascular endothelial cells with the cell layer.

To examine the possibility that $\mathrm{Ca}-\mathrm{SP}$ and $\mathrm{Na}-$ SP stimulate the release of proteoglycans associated with the vascular endothelial cell layer, the cells prelabeled with $\left[{ }^{35} \mathrm{~S}\right]$ sulfate were treated with $\mathrm{Ca}$ $\mathrm{SP}$ and the release of proteoglycans was determined. As shown in Fig. 2, the proteoglycan release was significantly increased by $\mathrm{Ca}-\mathrm{SP}$ in a dose-dependent manner, indicating that $\mathrm{Ca}$-SP not only inhibits the association of newly synthesized proteoglycans with the cell layer but also stimulates the release of cell-associated proteoglycans to the liquid phase. Na$\mathrm{SP}$ also stimulates the release of proteoglycans from endothelial cell layers in a fashion equal to that of Ca-SP (not shown).

Figure 3 shows the DEAE-Sephacel profiles of $\left[{ }^{35} \mathrm{~S}\right]$ sulfate-labeled proteoglycans released from the cell layers of vascular endothelial cells treated with or without $\mathrm{Na}$-SP. It was shown that $\mathrm{Na}-\mathrm{SP}$ stimulates the release of both HSPGs and CS/DS PGs from the cell layer. 


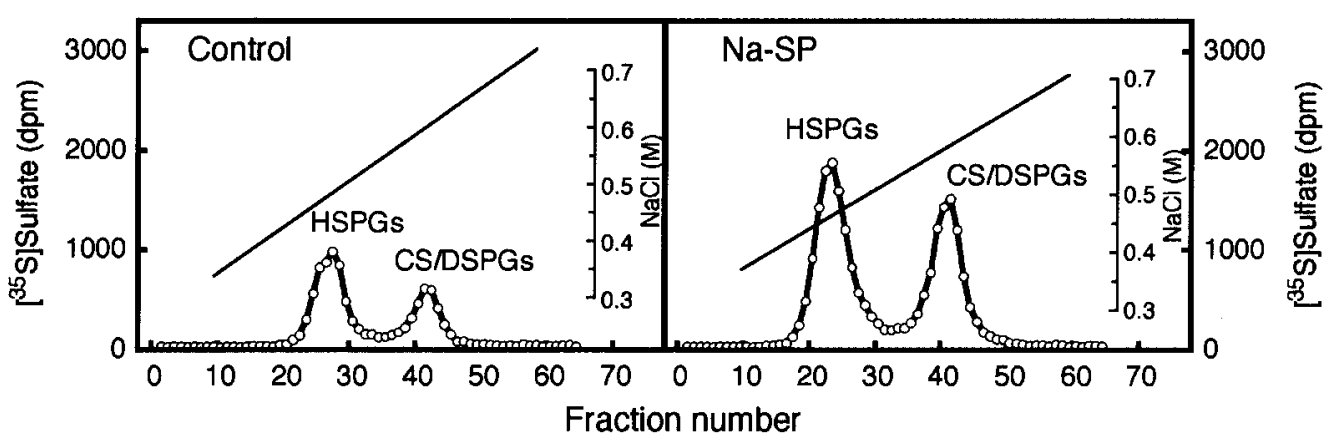

Fig. 3. DEAE-Sephacel Ion-exchange Chromatography of $\left[{ }^{35} \mathrm{~S}\right]$ Sulfate-labeled Proteoglycans Extracted from the Conditioned Medium of Vascular Endothelial Cells Treated with Na-SP for $3 \mathrm{hr}$ with a Linear Gradient of 0.25 to $0.7 \mathrm{M} \mathrm{NaCl}$ in $8 \mathrm{M}$ Urea Buffer.

Confluent cultures of bovine aortic endothelial cells were labeled with $\left[{ }^{35} \mathrm{~S}\right]$ sulfate and then incubated at $37^{\circ} \mathrm{C}$ for $3 \mathrm{hr}$ with Na-SP $(10 \mu \mathrm{g} / \mathrm{ml})$ in the absence of $\left[{ }^{35} \mathrm{~S}\right]$ sulfate. Confluent cultures of bovine aortic endothelial cells were labeled with $\left.{ }^{35} \mathrm{~S}\right]$ sulfate and then incubated at $37^{\circ} \mathrm{C}$ for $1 \mathrm{hr}$ with CaSP $(2.5,5,10$ or $25 \mu \mathrm{g} / \mathrm{ml})$ in the absence of $\left[{ }^{35} \mathrm{~S}\right]$ sulfate.

\section{DISCUSSION}

In the present study, $\mathrm{Ca}-\mathrm{SP}$ and $\mathrm{Na}-\mathrm{SP}$ were found to inhibit the association of proteoglycans with vascular endothelial cells; as the result, release of cell-associated proteoglycans was also promoted by the polysaccharides. It was shown earlier that heparin is a unique sulfated polysaccharide that stimulates the release of proteoglycans from the vascular endothelial cell layer. ${ }^{17)}$ Other polysaccharides including heparan sulfate, chondroitin sulfate, dermatan sulfate and hyaluronan as well as low molecular weight heparin do not exhibit such a stimulatory activity, ${ }^{17)}$ suggesting that stimulation of endothelial proteoglycan release is not a general effect of (sulfated) polysaccharide. Thus, it is indicated that $\mathrm{Ca}-\mathrm{SP}$ and Na-SP are also unique sulfated polysaccharides that accelerate endothelial proteoglycan release like heparin. Since heparin is postulated to exhibit the antithrombin activity not only by activating antithrombin III and heparin cofactor II in the blood but also by stimulating the release of anticoagulant heparan sulfate on the surface of the vascular endothelium, it is likely that $\mathrm{Ca}$ $\mathrm{SP}$ and Na-SP also may exhibit antithrombin activity by a similar mechanism in the blood.

Proteoglycans synthesized and secreted by vascular endothelial cells are involved in the regulation of functions of the cells. For example, heparan sulfate chains of perlecan promote the binding of basic fibroblast growth factor, which stimulates the proliferation of the cells as an autocrine ${ }^{18)}$ to the receptor. ${ }^{19)}$ On the other hand, the core protein of biglycan binds transforming growth factor- $\beta$, which inhibits endothelial cell proliferation, ${ }^{20)}$ and sequesters the cytokine from the cell surface receptor. ${ }^{21)}$ Since it was suggested that $\mathrm{Ca}-\mathrm{SP}$ and $\mathrm{Na}-\mathrm{SP}$ inhibit the association of both HSPGs and CS/DS PGs, resulting in a decrease in both types of newly synthesized proteoglycans in endothelial cell layers, the polysaccharides may influence the regulation of function of the cells by basic fibroblast growth factor and transforming growth factor- $\beta$. In fact, we have shown that $\mathrm{Ca}-\mathrm{SP}$ inhibits the proliferation of vascular endothelial cells by inducing a lower ability to respond to stimulation by endogenous basic fibroblast growth factor. ${ }^{15)}$

Although it has been reported that endothelial proteoglycan synthesis is modulated by several factors including transforming growth factor- $\beta_{1},{ }^{10}$ ) interleukin- $1 \beta^{22)}$ and tumor necrosis factor- $\alpha,{ }^{23)}$ little is known about the regulation of the secretion. It was suggested that activation of protein kinase $C$ stimulates the release of either HSPGs and CS/DS PGs from cultured vascular endothelial cells. ${ }^{24)}$ Thus, although it is possible that $\mathrm{Ca}-\mathrm{SP}$ and Na-SP physicochemically compete with HSPGs and CS/ DS PGs at their binding sites to other components of extracellular matrix in endothelial cells, it is also possible for the polysaccharides to influence the intracellular signal transduction such as protein kinase $\mathrm{C}$ by stimulation of some receptors. However, this remains to be confirmed.

In conclusion, it was found that novel sulfated polysaccharides from Spilurina platensis $\mathrm{Ca}-\mathrm{SP}$ and Na-SP inhibit the association of HSPGs and CS/DS PGs with vascular endothelial cell layers. It is suggested that either $\mathrm{Ca}-\mathrm{SP}$ or $\mathrm{Na}-\mathrm{SP}$ influences the functions of vascular endothelial cells regulated by autocrine and paracrine mediators such as basic fibroblast growth factor through alteration of the proteoglycan metabolism. Further studies are nec- 
essary to clarify whether or not Ca-SP and Na-SP have beneficial effects as anticoagulant agents on the blood coagulation-fibrinolytic system through not only activation of heparin cofactor II but also influence upon vascular endothelial cell function.

Acknowledgements The study was partly supported by the Special Research Fund of Hokuriku University (to T. K.).

\section{REFERENCES}

1) Hayashi, T., Hayashi, K., Maeda, M. and Kojima, I. (1996) Calcium spirulan, an inhibitor of enveloped virus replication, from a blue-green alga Spirulina platensis. J. Nat. Prod., 59, 83-87.

2) Hayashi, K., Hayashi, T. and Kojima, I. (1996) A natural sulfated polysaccharide, calcium spirulan, isolated from Spirulina platensis: in vitro and $e x$ vivo evaluation of anti-herpes simplex virus and antihuman immunodeficiency virus activities. AIDS Res. Hum. Retroviruses, 12, 1463-1471.

3) Lee, J. B., Hayashi, T., Hayashi, K., Sankawa, U., Maeda, M., Nemoto, T. and Nakanishi, H. (1998) Further purification and structural analysis of calcium spirulan from Spirulina platensis. J. Nat. Prod., 61, 1101-1104.

4) Lee, J. B., Hayashi, T., Hayashi, K. and Sankawa, U. (2000) Structural analysis of calcium spirulan (Ca-SP)-derived oligosaccharides using electrospray ionization mass spectrometry. J. Nat. Prod., 63, 136138.

5) Hayakawa, Y., Hayashi, T., Hayashi, K., Hayashi, T., Ozawa, T., Niiya, K. and Sakuragawa, N. (1996) Heparin cofactor II-dependent antithrombin activity of calcium spirulan. Blood Coagul. Fibrinolysis, 7 , 554-560.

6) Hayakawa, Y., Hayashi, T., Lee, J. B., Ozawa, T. and Sakuragawa, N. (2000) Activation of heparin cofactor II by calcium spirulan. J. Biol. Chem., 275, 11379-11382.

7) Hayakawa, Y., Hayashi, T., Hayashi, K., Ozawa, T., Niiya, K. and Sakuragawa, N. (1997) Calcium spirulan as an inducer of tissue-type plasminogen activator in human fetal lung fibroblasts. Biochim. Biophys. Acta., 1355, 241-247.

8) Weksler, B. B., Ley, C. W. and Jaffe, E. A. (1978) Stimulation of endothelial cell prostaglandin production by thrombin, trypsin and the ionophore A23187. J. Clin. Invest., 62, 923-930.

9) Levin, E. G. and Loskutoff, D. J. (1982) Cultured bovine aortic endothelial cells produce both urokinase and tissue-plasminogen activators. J. Cell
Biol., 94, 631-636.

10) Kaji, T., Yamada, A., Miyajima, S., Yamamoto, C., Fujiwara, Y., Wight, T. N. and Kinsella, M. G. (2000) Cell density-dependent regulation of proteoglycan synthesis by transforming growth factor- $\beta_{1}$ in cultured bovine aortic endothelial cells. J. Biol. Chem., 275, 1463-1470.

11) Mertens, G., Cassiman, J. J., Van den Berghe, H., Vermylen, J. and David, G. (1992) Cell surface heparan sulfate proteoglycans from human vascular endothelial cells. Core protein characterization and antithrombin III binding properties. J. Biol. Chem., 267, 20435-20443.

12) Whinna, H. C., Choi, H. U., Rosenberg, L. C. and Church, F. C. (1993) Interaction of heparin cofactor II with biglycan and decorin. J. Biol. Chem., 268, 3920-3924.

13) Fujiwara, Y. and Kaji, T. (2000) Inhibition of the repair of injured endothelial cell monolayers by lead and its possible mechanisms. J. Health Sci., 46, 1-4.

14) Kaji, T., Miyajima, S., Yamamoto, C., Fujiwara, Y., Sakurai, S., Yamagishi, S., Sueishi, K. and Yamamoto, H. (2000) Selective increase in decorin mRNA level in cultured vascular smooth muscle cells after exposure to advanced glycation endproducts. J. Health Sci., 46, 223-227.

15) Kaji, T., Fujiwara, Y., Inomata, Y., Hamada, C., Yamamoto, C., Shimada, S., Lee, J. B. and Hayashi, T. (2002) Repair of wounded monolayers of cultured bovine aortic endothelial cells is inhibited by calcium spirulan, a novel sulfated polysaccharide isolated from Spirulina platensis. Life Sci., 70, 1841-1848.

16) Wasteson, Å., Uthne, K. and Westermark, B. (1973) A novel assay for the biosynthesis of sulphated polysaccharide and its application to studies on the effects of somatomedin on cultured cells. Biochem. J., 136, 1069-1074.

17) Kaji, T. and Sakuragawa, N. (1990) Heparin stimulates the release of glycosaminoglycans from cultured human endothelial cells. Thromb. Res., 57, 163-168.

18) Schweigerer, L., Newfeld, D. G., Friedman, J., Abraham, J. A., Fiddes, J. C. and Gospodarowicz, D. (1987) Capillary endothelial cells express basic fibroblast growth factor, a mitogen that promotes their own growth. Nature (London), 325, 257-259.

19) Avizer, D., Hecht, D., Safran, M., Eisinger, M., David, G. and Yayon, A. (1994) Perlecan, basal lamina proteoglycan, promotes basic fibroblast growth factor-receptor binding, mitogenesis and angiogenesis. Cell, 79, 1005-1013.

20) Fráter-Schröder, M., Müller, G., Birchmeier, W. and Bölen, P. (1986) Transforming growth factor-beta inhibits endothelial cell proliferation. Biochem. Biophys. Res. Commun., 137, 295-302. 
21) Hildebrand, A., Romaris, M., Rasmussen, L. M., Heinegård, D., Twardzik, D. R., Border, W. A. and Ruoslahti, E. (1994) Interaction of the small interstitial proteoglycan, biglycan, decorin and fibromodulin with transforming growth factor beta. Biochem. J., 302, 527-534.

22) Skop, B., Sobczak, A., Drozdz, M. and KotrysPuchlska, E. (1996) Comparison of the action of transforming growth factor- $\beta_{1}$ and interleukin- $1 \beta$ on matrix metabolism in the culture of porcine endothelial cells. Biochemie, 78, 103-107.
23) Ramasamy, S., Lipke, D. W., McClain, C. J. and Hennig, B. (1995) Tumor necrosis factor reduces proteoglycan synthesis in cultured endothelial cells. J. Cell. Physiol., 162, 119-126.

24) Fujii, N., Kaji, T., Yamamoto, C., Fujiwara, Y. and Koizumi, F. (1996) Phorbol 12-myristate 13-acetate stimulates the release of glycosaminoglycans from cultured vascular endothelial cells: Possible involvement of protein kinase $\mathrm{C}$ activation. Thromb. Res., 82, 379-387. 